\title{
DNA extraction from long-term stored urine
}

\author{
Marc Hilhorst, Ruud Theunissen, Henk van Rie, Pieter van Paassen and Jan Willem Cohen Tervaert
}

\begin{abstract}
Background: Traditionally, for DNA analyses, DNA is recovered from buffy coats. Since DNA in urine has been reported to deteriorate quickly, this option is often not considered. To complete our DNA database in patients with ANCA-associated vasculitis, we aimed to extract DNA from stored urine.

Methods: Urine was stored at the time of kidney biopsy from patients included in our regional kidney biopsy database, who had given informed consent for further study. Urine was subsequently filtered, dialyzed, concentrated and freeze dried and finallyresolubilized and centrifuged. DNA was extracted using the high pure PCR template preparation kit (Roche Diagnostics). Next, concentration and purity were determined by Nanodrop analysis and by Quant-iT analysis.

Results: One hundred and eighty-one patients with ANCA-associated vasculitis were included. Of 114 patients (63\%), DNA was available. From 53 of the remaining 67 patients, stored urine was available. Of the 53 samples that were processed, 46 (86.8\%) yielded DNA with a mean concentration of $258.7 \mathrm{ng} / \mu \mathrm{L}$ (range 33.2-529) with a mean purity ratio of 1.81 ( $\lambda$ 260/280).

Conclusion: DNA extraction from fresh urine has been described before, yielding DNA usable for PCR analysis in healthy subjects. Storage of fresh urine at $4^{\circ} \mathrm{C}$ or lower temperatures results in significant degradation of the DNA, making recovery of DNA more difficult with longer periods of storage. In the current study, we demonstrated that DNA could be retrieved from subsequently filtered, dialyzed, concentrated and freeze dried urine that was stored at room temperature. In addition, we demonstrated that this DNA could be used for PCR analysis. This method is useful when no other material from these patients is available.
\end{abstract}

Keywords: DNA, Urine, Vasculitis

\section{Background}

Genetic factors have been studied by analysis of DNA in many different diseases. In anti-neutrophil cytoplasmic antibody (ANCA)-associated vasculitis, the relevance of this analysis was shown in a genomewide association study [1]. Traditionally, for these analyses, DNA is recovered from buffy coats. Since DNA in urine has been reported to deteriorate quickly [2], urine is generally not used for the purpose of DNA analysis.

We postulate that it is possible to extract DNA from appropriately stored urine from patients with ANCAassociated glomerulonephritis.

\footnotetext{
* Correspondence: jw.cohentervaert@maastrichtuniversity.nl

Clinical \& Experimental Immunology, Maastricht University, P.O. Box 5800, 6202 AZ Maastricht, The Netherlands
}

\section{() Biomed Central

(c) 2013 Hilhorst et al.; licensee BioMed Central Ltd. This is an open access article distributed under the terms of the Creative Commons Attribution License (http://creativecommons.org/licenses/by/2.0), which permits unrestricted use, distribution, and reproduction in any medium, provided the original work is properly cited.

\section{Methods}

The Limburg Renal Registry [3] was searched to identify all ANCA positive patients with pauci-immune necrotizing crescentic glomerulonephritis in order to perform DNA analysis. Patients from who no buffy coats and/or tissue was available but who had given consent for further study, were included in the current study. The local Medical Research Ethics Committee of the Maastricht University Medical Centre approved the study.

Exclusion criteria were concomitant renal diseases such as diabetic nephropathy, thin GBM glomerulopathy or anti-GBM glomerulonephritis.

At the time of renal disease, urine of patients was filtered by passing it through a paper filter. The urine was then dialyzed and concentrated in a Proflux $M 12^{\circ}$ (Millipore, Billerica, MA, USA). Dialyzed and concentrated urine was subsequently snap frozen in a bath of liquid nitrogen and dried in a Beta $1-8 \mathrm{LD}^{\circ}$ freeze dryer (Christ, Osterode, Germany). Samples were subsequently stored at 
room temperature until use. For this purpose, 0.2 grams of freeze dried urine was resolubilized in $20 \mathrm{~mL}$ of MilliQ and left it stirring overnight at $4^{\circ} \mathrm{C}$. We next centrifuged the urine samples for 10 minutes at $10000 \mathrm{~g}$. We extracted DNA by using the high pure PCR template preparation kit (Roche Molecular Diagnostics, Mannheim, Germany). Briefly, the supernatant was decanted and the sediment dissolved in $50 \mu \mathrm{L}$ proteinase $\mathrm{K}$ in $1 \mathrm{~mL}$ of binding buffer (6 $\mathrm{M}$ guaninidine- $\mathrm{HCl}, 10 \mathrm{mM}$ urea, $10 \mathrm{mM}$ Tris- $\mathrm{HCl}$, $20 \%$ Triton $\mathrm{X}-100, \mathrm{pH} 4.4)$. After a ten minute incubation at $56^{\circ} \mathrm{C}, 100 \mu \mathrm{L}$ of iso-propanol was added and the solution was centrifuged through a filtertube containing glass fibers for 1 minute at $8000 \mathrm{~g}$. The filtertube was subsequently centrifuged with $500 \mu \mathrm{L}$ of inhibitor removal buffer (5 M guaninidine- $\mathrm{HCl}, 20 \mathrm{mM}$ Tris- $\mathrm{HCl}, 45 \%$ ethanol, $\mathrm{pH}$ 6.6) for 1 minute at $8000 \mathrm{~g}$ and washed three times with wash buffer $(20 \mathrm{mM} \mathrm{NaCl}, 2 \mathrm{mM}$ Tris- $\mathrm{HCl}, 80 \%$ ethanol, pH 7.5) for 1 minute at $8000 \mathrm{~g}$. The DNA on the glass fibers was then eluted in $200 \mu \mathrm{L}$ of elution buffer by centrifuging for 1 minute at $8000 \mathrm{~g}$ and measured for concentration and purity on a NanoDrop ${ }^{\circledR}$ Spectrophotometer (Nanodrop Technologies, Wilmingtom, DE, USA). In addition, DNA was measured using the Quant-iT ${ }^{\mathrm{TM}}$ Picogreen $^{\otimes}$ dsDNA assay. This is an ultrasensitive fluorescent nucleic acid staining for quantitating small amounts of double stranded DNA [4].

\section{Results}

In the current study, 181 consecutive patients with ANCA-associated glomerulonephritis were included. Of 114 patients (63\%) DNA was available. From 53 of the remaining 67 patients, 24 hour freeze dried urine was available.

Freeze dried urine from these patients had been stored at room temperature for an average time of 16 years (range 6-28). Of the 53 samples that were processed, $46(86.8 \%)$ yielded DNA with a mean concentration of $258.7 \mathrm{ng} / \mu \mathrm{L}$ (range 33.2-529) with a mean purity ratio of $1.81(\lambda 260 / 280)$ as measured on a Nanodrop 2100. Eleven samples were further diluted for picogreen analysis. These samples were found to contain DNA in an average concentration of $40 \mathrm{ng} / \mu \mathrm{L}$ on the Nanodrop ${ }^{\circ}$ 2100 and an average concentration of dsDNA of $23.35 \mathrm{ng} / \mu \mathrm{L}$ by picogreen analysis. Polymorphisms in several genes (CTLA-4, PD1) could be determined in $38(82.6 \%)$ of these samples [5] (Figure 1). Linear regression showed that the amount of DNA extracted from the urine did not correlate with the amount of proteinuria at the time of urine storage $\left(\mathrm{R}^{2}=0.02 ; \mathrm{p}=0.34\right)$ or the length of time that the urine was stored $\left(R^{2}=0.08\right.$; $\mathrm{p}=0.55)$. Furthermore, Chi-square analysis proved gender to be of no significance $(\mathrm{p}=0.8)$ yielding signals in $87.5 \%$ of males and in $54.5 \%$ of females. Finally, gel electrophoresis with PCR products from DNA from urine and from

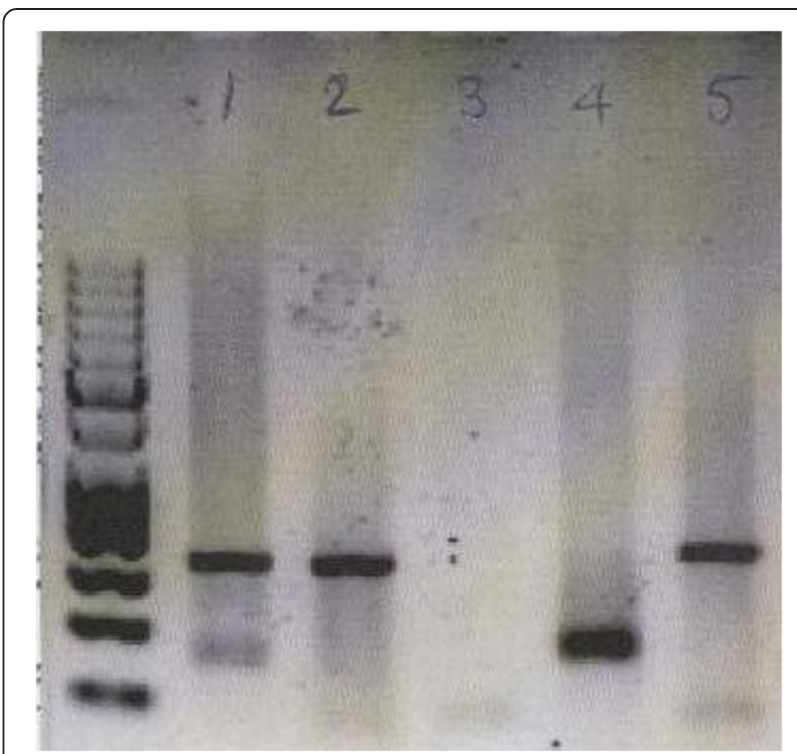

Figure 1 CTLA-4 +49 polymorphism analyses from 5 patients on DNA retrieved from urine. Patient 1 had the AG genotype, patient $2 \mathrm{AA}$, patient 3 non-detectable, patient $4 \mathrm{GG}$ and patient $5 \mathrm{AA}$.

buffy coat of three patients showed similar bands in varying magnitude (Figure 2).

\section{Discussion}

DNA extraction from fresh urine has been described before, yielding DNA usable for PCR analysis in up to $35 \%$ of healthy males and up to $75 \%$ of healthy females

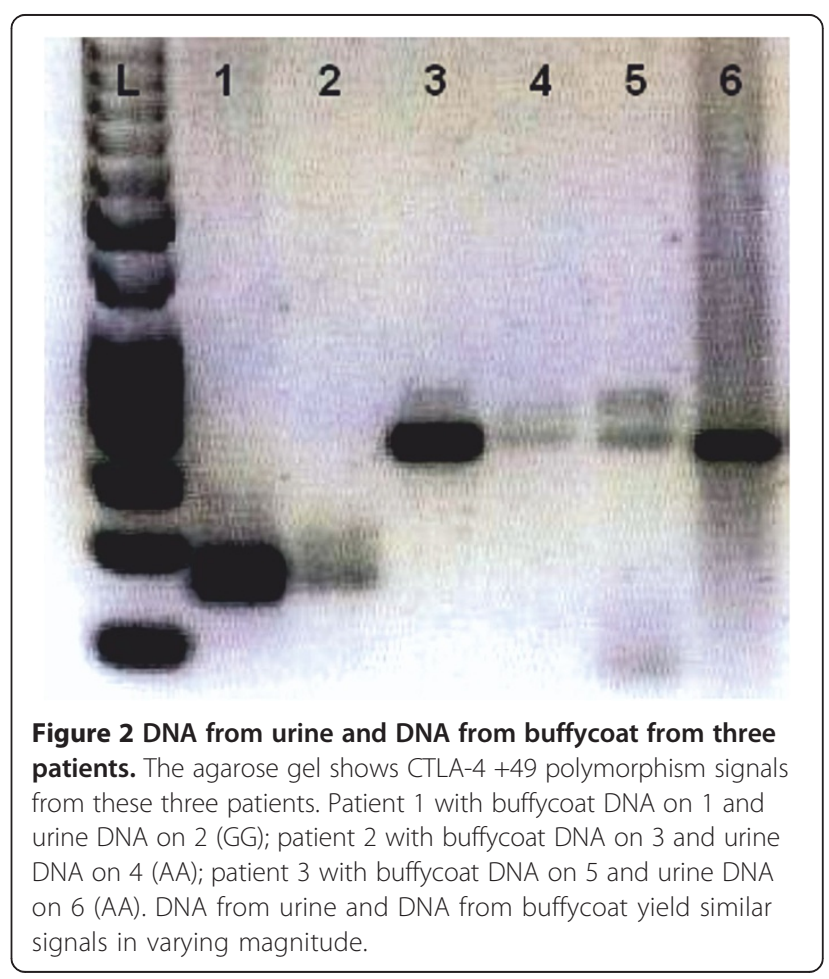


$[2,6,7]$. Storage of fresh urine at $4^{\circ} \mathrm{C}$ or lower temperatures results in significant degradation of human DNA, resulting in low recovery rates during long-term storage [8-13]. When urine is stored at $-20^{\circ} \mathrm{C}$, around $75 \%$ of the DNA degrades within 28 days $[11,14]$, making a quantitative recovery difficult after this period [9]. A temperature of $-80^{\circ} \mathrm{C}$ improves recovery up to 28 days of storage but increases storage costs $[15,16]$. Importantly, however, Fernandez-Soto et al. reported that it was not possible to recover DNA for PCR analysis from urine samples stored at $-80^{\circ} \mathrm{C}$ after storage of 18 months up to 7 years [15]. Adding sodium azide or EDTA has been reported to improve the recovery of DNA $[8,12,17,18]$. No studies, however, have reported data on DNA recovery from samples stored at $-80^{\circ} \mathrm{C}$ with the addition of azide or EDTA. At all temperatures, however, recovery of human DNA after longer periods of storage seems to be difficult. In the current study, we demonstrated that human DNA could be retrieved from freeze dried urine that could be used for PCR analysis, after an average storage period of 16 years at room temperature. Analysis by eosin and haematoxylin (H\&E) staining demonstrated damaged but intact cells with intact nuclei in the urinary sediment. Within these cells, leukocytes were present that stained positive with anti-CD45 (data not shown). The cells are clustered around debris in the sediment suggesting that this debris may have protected the cells from degradation during all these years.

\section{Conclusion}

We conclude that in case of deceased or lost-to-follow-up patients, DNA can be retrieved from successively dialyzed, concentrated, and freeze dried urine that has been stored for up to 28 years.

\section{Abbreviations}

DNA: Deoxyribonucleic acid; ANCA: Anti-neutrophil cytoplasmic antibodies; GBM: Glomerular basement membrane; PCR: Polymerase chain reaction.

\section{Competing interests}

The authors declare that they have no competing interests.

\section{Authors' contributions}

$\mathrm{MH}, \mathrm{RT}$ and HvR performed extraction of DNA and critical revision of the manuscript. $\mathrm{MH}$ and JWCT contributed to the concept of study, interpretation of data, draft of the manuscript and critical revision of the manuscript. PvP contributed to concept of study, interpretation of data and critical revision of the manuscript. All authors have given final approval of the manuscript to be submitted.

\section{Acknowledgements}

We gratefully thank N. Bijnens and P. Heerings-Rewinkel (Laboratory of Clinical Immunology, Maastricht University Medical Center, Maastricht) for assistance. This study was performed for the Limburg Renal Registry.

\section{References}

1. Lyons P, Rayner T, Trivedi S, Holle J, Watts R, Jayne D, et al: Genetically Distinct Subsets within ANCA-Associated Vasculitis. N Engl J Med 2012, 367:214-223.

2. Yokota M, Tatsumi N, Tsuda I, Takubo T, Hiyoshi M: DNA extraction from urinary sediment. J Clin Lab Anal 1998, 12:88-91.

3. Hilhorst M, Wilde B, Van Paassen P, Winkens B, Van Breda VP, Cohen Tervaert JW, et al: Improved outcome in anti-neutrophil cytoplasmic antibody (ANCA)-associated glomerulonephritis: a 30-year follow-up study. Nephrol Dial Transplant 2013, 28:373-379.

4. Ahn SJ, Costa J, Emanuel JR: PicoGreen Quantitation of DNA: Effective Evaluation of Samples Pre-or Post-PCR. Nucl Acids Res. 1996, 24:2623-2625.

5. Slot M, Sokolowska M, Savelkouls K, Janssen R, Damoiseaux J, Cohen TJ: Immunoregulatory gene polymorphisms are associated with ANCA-related vasculitis. Clin Immunol 2008, 128:39-45.

6. Brinkmann B, Rand S, Bajanowski T: Forensic identification of urine samples. Int J Leg Med 1992, 105:59-61.

7. Botezatu I, Serdyuk O, Potapova G, Shelepov V, Alechina R, Molyaka Y, et al: Genetic analysis of DNA excreted in urine: a new approach for detecting specific genomic DNA sequences from cells dying in an organism. Clin Chem 2000, 46:1078-1084.

8. Vu N, Chaturvedi A, Canfield D: Genotyping for DQA1 and PM loci in urine using PCR-based amplification: effects of sample volume, storage temperature, preservatives, and aging on DNA extraction and typing. Forensic Sci Int 1999, 102:23-34

9. Van der Hel $O$, Van der Luijt $R$, de Mesquita Bueno $H$, Van Noord $P$, Slothouber B, Roest M, et al: Quality and quantity of DNA isolated from frozen urine in population-based research. Anal Biochem 2002, 304:206-211.

10. Prinz $M$, Grellner W, Schmitt C: DNA typing of urine samples following several years of storage. Int J Leg Med 1993, 106:75-79.

11. Cannas A, Kalunga G, Green C, Calvo L, Katemangwe P, Reihter K, et al: Implications of storing urinary DNA from different populations for molecular analyses. PloS One 2009, 4:e6985.

12. Ingersoll J, Bythwood T, Abdul-Ali D, Wingood G, Diclemente R, Caliendo A: Stability of Trichomonas vaginalis DNA in Urine Specimens. J Clin Microbiol 2008, 46:1628-1630.

13. Bryzgunova O, Skvortsova T, Kolesnikova E, Starikov A, Rykova E, Vlassov V, et al: Isolation and Comparative Study of Cell-Free Nucleic Acids from Human Urine. Ann N Y Acad Sci 2006, 1075:334-340.

14. Morré S, Van Valkengoed I, De Jong A, Boeke A, Van Eijk J, Meijer C, et al: Mailed, home-obtained urine specimens: a reliable screening approach for detecting asymptomatic Chlamydia trachomatis infections. J Clin Microbiol 1999, 37:976-980.

15. Fernández-Soto P, Velasco Tirado V, Carranza Rodriguez C, Perez-Arellano J, Muro A: Long-Term Frozen Storage of Urine Samples: A Trouble to Get PCR Results in Schistosoma spp. DNA Detection? PloS One 2013, 8:e61703.

16. Elliott $P$, Peakman $T$ : The UK Biobank sample handling and storage protocol for the collection, processing and archiving of human blood and urine. Int J Epidemiol 2008, 37:234-244.

17. Milde A, Haas-Rochholz H, Kaatsch H: Improved DNA typing of human urine by adding EDTA. Int J Leg Med 1999, 112:209-210.

18. Saetun $P$, Semangoen $T$, Thongboonkerd $V$ : Characterizations of urinary sediments precipitated after freezing and their effects on urinary protein and chemical analyses. Am J Physiol Renal Physiol 2009, 296:F1346-F1354.

doi:10.1186/1471-2369-14-238

Cite this article as: Hilhorst et al:: DNA extraction from long-term stored urine. BMC Nephrology 2013 14:238. 